\title{
Acute phase reactants in the follow-up of patients with FMF
}

\author{
ZS ArıcI, ED Batu, E Sönmez, Y Bilginer, R Topaloğlu, S Özen \\ From 8th International Congress of Familial Mediterranean Fever and Systemic Autoinflammatory Diseases \\ Dresden, Germany. 30 September - 3 October 2015
}

\section{Introduction}

Familial Mediterranean Fever (FMF) is the most common periodic fever syndrome. FMF characterized by recurrent fever, serositis attacks and chronic subclinical inflammation in attack-free periods.

\section{Objective}

The aim of this study was to evaluate the relevance of acute phase reactants (APR) in FMF and to determine their correlation with each other during attacks and attack-free periods.

\section{Methods}

Twenty-three children diagnosed as FMF according to the previously published criteria and followed-up at the Pediatric Rheumatology Clinic of Hacettepe Children's Hospital were enrolled in the study. The erythrocyte sedimentation rate (ESR), $C$ reactive protein $(C R P)$, white blood cell (WBC) count, platelet count, and serum amyloid a (SAA) were tested in the patients during an attack and in-between attacks.

\section{Results}

There were 9 male and 14 female patients. Tests were performed in 11 patients with an attack and in 12 without attacks. All patient had homozygous or compound heterozygous FMF-associated mutations. ESR, CRP, WBC, SAA were statistically significantly higher in patients with an attack (respectively $\mathrm{p}<0,001$, p $<$ $0,001, p=0.03, p=0,003$ ). Highly significant and perfect correlation was found between SAA and CRP in patients with attack $(r=0,939, p<0,001)$.

There was a significant correlation between the number of attacks in the last 6 months and SAA in the

Hacettepe University, Pediatric Rheumatology, Ankara, Turkey patient with attack-free periods $(\mathrm{r}=0,746, \mathrm{p}=0,005)$. There was no other significant correlation.

\section{Conclusion}

CRP and SAA levels correlated with each other during the FMF attacks. SAA is important to identify subclinical inflammation in FMF patients when other APRs were normal.

Published: 28 September 2015

doi:10.1186/1546-0096-13-S1-P115

Cite this article as: Arıcl et al:: Acute phase reactants in the follow-up of patients with FMF. Pediatric Rheumatology 2015 13(Suppl 1):P115.

\section{Submit your next manuscript to BioMed Central and take full advantage of: \\ - Convenient online submission \\ - Thorough peer review \\ - No space constraints or color figure charges \\ - Immediate publication on acceptance \\ - Inclusion in PubMed, CAS, Scopus and Google Scholar \\ - Research which is freely available for redistribution

